\title{
Practice and Awareness Regarding Tobacco Consumption among Residents of the Hilly area of Eastern Region of Nepal
}

\author{
Ram Bilakshan Sah ${ }^{1}$, Laxmi Subedi ${ }^{1}$, Nilambar Jha
}

${ }^{1}$ School of Public Health and Community Medicine, BPKIHS, Dharan

\begin{abstract}
Introduction: Tobacco use is a global socio-economic hazard and medical malady. The incidence of tobacco is persisting and spreading in all walks of our modern society.

Methods: The cross-sectional study was conducted among residents of Dhankuta Municipality where 205 households were taken as subjects. Pretested semi-structured questionnaire was administered to the study subjects and face to face interview was conducted. Chi-square test was applied to find out the association between pattern of tobacco use and awareness of tobacco use among residents of Dhankuta municipality.

Results: The awareness towards tobacco use among residents of Dhankuta municipality was found to be $41 \%$. The awareness of tobacco consumption was significantly higher among the female (49\%) in gender and those whose education were School Leaving Certificate (SLC) and above $(44.6 \%)(P<0.05)$. The respondents consuming tobacco have forty times lesser chances of having aware as respondents not consuming tobacco $(\mathrm{OR}=\mathbf{0 . 0 2 5})$. The respondents consuming tobacco for more than 20 years $(\mathbf{1 2 . 1 \% )}$ and more than 20 sticks per day $(20 \%)$ were more aware of tobacco consumption but the difference was not significant.
\end{abstract}

Conclusions: The awareness towards tobacco use among residents of Dhankuta municipality was found to be less. Male in gender, lack of education and poor occupation like famer, housewife was found to be less aware of tobacco consumption.

Keywords: awareness; tobacco consumption; quality of life.

\section{INTRODUCTION}

Tobacco use is one of the leading preventable causes of premature death, disease and disability around the world ${ }^{1}$. Tobacco use is one of the risk factors for six out of eight leading causes of death worldwide ${ }^{2}$. An estimated 4.9 million deaths occurring annually can be attributed to tobacco use. This may increase to 10 million by the year 2020, if the current tobacco use epidemic continues and more than $70 \%$ of these deaths are expected to occur in developing countries ${ }^{3}$.

In Nepal, chronic non-communicable diseases account for $42 \%$ of all the deaths ${ }^{4}$. This rate may be due to a high prevalence of current daily tobacco users among men and women aged 17 years and above which was $48.5 \%$ and $24 \%$ respectively ${ }^{5}$. In the mountain region, the reported prevalence of females smoking was 71.6 $\%{ }^{6}$. Various studies have reported prevalence ranging from $20 \%$ to $72 \%$ in different populations of $\mathrm{Nepal}^{6.7}$.

\section{Correspondence:}

Dr. Ram Bilakshan Sah

School of Public Health \& Community Medicine, B. P. Koirala Institute of Health Sciences, Dharan, Nepal.

Email: bilaksah@Yahoo.com 
The Global Tobacco Surveillance System (GTSS) collaborative group has reported that tobacco use (both cigarette and smokeless tobacco) is high and has emphasized that interventions are necessary for the prevention of initiation and to promote cessation of tobacco among current users ${ }^{8}$. Therefore this study was designed to measure the prevalence of awareness of tobacco use and to find out the association between pattern of tobacco use and awareness of tobacco use among residents of Dhankuta municipality.

\section{METHODS}

The cross-sectional study was conducted from 1st July 2014 to 30th April 2015 among the residents of Dhankuta municipality of Nepal. Dhankuta is located in the eastern geographical region of Nepal. This research was based on random selection of the study area Dhankuta municipality. A National survey revealed that the prevalence of tobacco use was $33 \%$ (Khan $\mathrm{S}$ et al in India in 2013) ${ }^{9}$, more than that $45 \%$ (Karki YB et al Nepal in 2002) ${ }^{10}$ and highest $52.07 \%$ (Zahiruddin QS et al in India in 2011) ${ }^{11}$. So taking lower value $33 \%$ of prevalence of tobacco use, sample size was calculated at $95 \%$ CI \& $80 \%$ powers then it became 205 persons aged above 17 years. There are 9 wards in Dhankuta Municipality. Among 9 wards, 5 wards was randomly selected. The list of households of five selected wards was prepared and equal number of households (41) from each ward was selected on the basis of simple random sampling.
Ethical clearance was taken by Institutional Ethical Review Board of B P Koirala Institute of Health Sciences, Dharan, Nepal. Participants were first explained the purpose of study, its implications and assurance about the confidentiality of the information provided was given to the participants. Name of the individuals or participating group was not disclose after the study.

Written permission was taken from concerned authority (head of house) and the participants of the study. Those individuals who were available after three visits and willing to give written consents were included in the study. Pretested semi-structured questionnaire was administered to the study subjects in the presence of investigator and face to face interview was conducted.

The collected data was entered in MS Excel 2000. The quantitative data was analyzed using Statistical Package for the Social Sciences (SPSS) software package. Odds ratio and prevalence was calculated, Chi-square test was applied to find out the association between pattern of tobacco use and awareness of tobacco consumption. The probability of occurrence by chance is significant if $\mathrm{P}<0.05$ with $95 \%$ Confidence Interval.

\section{RESULTS}

Table 1. Association between sociodemographic characteristics and awareness of tobacco

consumption $(\mathrm{N}=\mathbf{2 0 5})$

\begin{tabular}{|c|c|c|c|c|}
\hline \multirow[t]{2}{*}{ Characteristics } & \multicolumn{2}{|c|}{$\begin{array}{c}\text { Awareness of tobacco } \\
\text { consumption }\end{array}$} & \multirow[t]{2}{*}{ Total } & \multirow[t]{2}{*}{ P-value } \\
\hline & Yes & No & & \\
\hline \multicolumn{5}{|l|}{ Age } \\
\hline $17-40$ years & $60(42.9)$ & $80(57.1)$ & 140 & 0.696 \\
\hline $41-59$ years & $20(37.7)$ & $33(62.3)$ & 53 & \\
\hline$\geq 60$ years & $4(33.3)$ & $8(66.7)$ & 12 & \\
\hline \multicolumn{5}{|l|}{ Gender } \\
\hline Male & $34(33.0)$ & $69(67.0)$ & 103 & 0.020 \\
\hline Female & $50(49.0)$ & $52(51.0)$ & 102 & \\
\hline
\end{tabular}


MJSBH January-June 2015|Vol 14| Issue 1

\begin{tabular}{|l|c|c|c|c|}
\hline Religion & & & \\
Hindu & $74(40.9)$ & $107(59.1)$ & 181 & 0.942 \\
Others (Buddhist, & $10(41.7)$ & $14(58.3)$ & 24 & \\
$\quad$ Christian, Muslim) & & & & \\
\hline Ethnicity & $25(33.8)$ & $49(66.2)$ & 74 & 0.080 \\
Brahmin/ Chhetri & $12(41,4)$ & $17(59.6)$ & 29 & \\
Kirati & $41(49.4)$ & $42(50.6)$ & 83 & \\
Janajati & $6(46.2)$ & $7(53.8)$ & 13 & \\
Dalit & $0(0.0)$ & $6(100.0)$ & 6 & \\
Terai caste & $12(25.0)$ & $36(75.0)$ & 48 & 0.035 \\
\hline Education of respondents & $35(47.3)$ & $39(52.7)$ & 74 & \\
Illiterate & $37(44.6)$ & $46(55.4)$ & 83 & \\
Below SLC & & & & \\
SLC and above & $26(41.9)$ & $36(58.1)$ & 62 & 0.027 \\
Occupation of respondents & $29(56.9)$ & $22(41.1)$ & 51 & \\
Service & $6(20.7)$ & $23(79.3)$ & 29 & \\
Business & $11(34.4)$ & $21(65.6)$ & 32 & \\
Farmer & $12(38.7)$ & $19(61.3)$ & 31 & \\
Housewife & & & \\
Others (students, abroad, & $\mathbf{8 4 ( 4 1 . 0 )}$ & $\mathbf{1 2 1 ( 5 9 . 0 )}$ & $\mathbf{2 0 5}$ & \\
labor, tailor, carpenter) & & & \\
Below poverty line(<1.25 US\$) & & & \\
Above poverty line ( $\geq 1.25$ US \$) & & & \\
\hline Economic status & & & \\
\hline
\end{tabular}

\section{SLC: School Leaving Certificate}

Table 1 shows overall awareness of the harmful consequences of tobacco consumption in Dhankuta Municipality was found to be $41 \%$. The awareness of tobacco consumption among the female was significantly higher than male $(\mathrm{P}<0.05)$. The awareness of tobacco consumption was recorded higher in those who were School Leaving Certificate (SLC) and above than illiterate $(\mathrm{P}<0.05)$. Regarding respondents occupation, awareness of tobacco consumption rate was found to be higher in business and service $(\mathrm{P}<0.05)$. 
MJSBH January-June 2015|Vol 14| Issue 1

Table 2. Association between pattern of tobacco use and awareness of tobacco consumption $(\mathrm{N}=\mathbf{2 0 5})$

\begin{tabular}{|c|c|c|c|c|c|}
\hline \multirow{2}{*}{ Characteristics } & \multicolumn{2}{|c|}{ Aware of tobacco consumption } & \multirow{2}{*}{ Total } & \multirow{2}{*}{$\begin{array}{l}\text { Odds } \\
\text { Ratio }\end{array}$} & \multirow{2}{*}{ P-value } \\
\hline & Yes & No & & & \\
\hline $\begin{array}{l}\text { Consume tobacco }(\mathrm{N}=205) \\
\text { Yes } \\
\text { No }\end{array}$ & $\begin{array}{l}12(10.3) \\
72(81.8)\end{array}$ & $\begin{array}{l}105(89.7) \\
16(18.2)\end{array}$ & $\begin{array}{c}117 \\
88\end{array}$ & 0.025 & $<0.001$ \\
\hline Total & $84(41.0)$ & $121(59.0)$ & 205 & & \\
\hline $\begin{array}{l}\text { If consume tobacco, then what form }(\mathrm{n}=117) \\
\text { Smoking } \\
\text { Chewing } \\
\text { Both }\end{array}$ & $\begin{array}{l}9(18.8) \\
0(0.0) \\
3(8.3)\end{array}$ & $\begin{array}{l}39(81.2) \\
33(100.0) \\
33(91.7)\end{array}$ & $\begin{array}{l}48 \\
33 \\
36\end{array}$ & & 0.022 \\
\hline Total & $12(10.3)$ & $105(89.7)$ & 117 & & \\
\hline $\begin{array}{l}\text { Duration of your habit till now }(\mathrm{n}=117) \\
\quad<10 \text { years } \\
10-20 \text { years } \\
>20 \text { years }\end{array}$ & $\begin{array}{l}4(9.3) \\
4(9.8) \\
4(12.1)\end{array}$ & $\begin{array}{l}39(90.7) \\
37(90.2) \\
29(87.9)\end{array}$ & $\begin{array}{l}43 \\
41 \\
33\end{array}$ & & 0.915 \\
\hline Total & $12(10.3)$ & $105(89.7)$ & 117 & & \\
\hline $\begin{array}{l}\text { If smoking then }(\mathrm{n}=84) \\
\text { Filtered } \\
\text { Unfiltered } \\
\text { Both }\end{array}$ & $\begin{array}{c}11(16.9) \\
0(0.0) \\
1(9.1)\end{array}$ & $\begin{array}{l}54(83.1) \\
8(100.0) \\
10(90.9)\end{array}$ & $\begin{array}{c}65 \\
8 \\
11\end{array}$ & & 0.378 \\
\hline Total & $12(14.3)$ & $72(85.7)$ & 84 & & \\
\hline $\begin{array}{l}\text { If smoking then number of sticks per day }(n=84) \\
\quad<10 \\
10-20 \\
>20\end{array}$ & $\begin{array}{l}9(17.6) \\
1(4.3) \\
2(20.0)\end{array}$ & $\begin{array}{c}42(82.4) \\
22(95.7) \\
8(80.0)\end{array}$ & $\begin{array}{l}51 \\
23 \\
10\end{array}$ & & 0.274 \\
\hline Total & $12(14.3)$ & $72(85.7)$ & 84 & & \\
\hline $\begin{array}{l}\text { Number of packets (chewing tobacco) per day } \\
(\mathrm{n}=69) \\
<2 \\
2-5\end{array}$ & $\begin{array}{l}3(5.0) \\
0(0.0)\end{array}$ & $\begin{array}{l}57(95.0) \\
9(100.0)\end{array}$ & $\begin{array}{c}60 \\
9\end{array}$ & 0.950 & 0.493 \\
\hline Total & $3(4.3)$ & $66(95.7)$ & 69 & & \\
\hline $\begin{array}{l}\text { How many times per day consume tobacco per } \\
\text { day }(\mathrm{n}=69) \\
\qquad \begin{array}{c}<10 \\
10-20\end{array}\end{array}$ & $\begin{array}{l}2(4.9) \\
1(3.6)\end{array}$ & $\begin{array}{l}39(95.1) \\
27(96.4)\end{array}$ & $\begin{array}{l}41 \\
28\end{array}$ & 1.385 & 0.794 \\
\hline Total & $3(4.3)$ & $66(95.7)$ & 69 & & \\
\hline $\begin{array}{l}\text { If no consume tobacco, then ever consume } \\
(\mathrm{n}=88) \\
\text { Yes } \\
\text { No }\end{array}$ & $\begin{array}{l}12(85.7) \\
60(81.1)\end{array}$ & $\begin{array}{l}2(14.3) \\
14(18.9)\end{array}$ & $\begin{array}{l}14 \\
74\end{array}$ & 1.400 & 0.680 \\
\hline $\begin{array}{l}\text { Total } \\
\end{array}$ & $72(81.8)$ & $16(18.2)$ & 88 & & \\
\hline $\begin{array}{l}\text { If ever consume then duration of consumption } \\
(\mathrm{n}=14) \\
\quad<10 \text { years } \\
10-20 \text { years }\end{array}$ & $\begin{array}{l}10(90.9) \\
2(66.7)\end{array}$ & $\begin{array}{l}1(9.1) \\
1(33.3)\end{array}$ & $\begin{array}{c}11 \\
3\end{array}$ & 5.000 & 0.287 \\
\hline Total & $12(85.7)$ & $2(14.3)$ & 14 & & \\
\hline $\begin{array}{l}\text { If ever consume then why leave tobacco } \\
\text { consumption }(n=14) \\
\text { Self interest } \\
\text { Old age }\end{array}$ & $\begin{array}{l}9(100.0) \\
3(60.0)\end{array}$ & $\begin{array}{c}0(0.0) \\
2(40.0)\end{array}$ & $\begin{array}{l}9 \\
5\end{array}$ & 1.667 & 0.040 \\
\hline Total & $12(85.7)$ & $2(14.3)$ & 14 & & \\
\hline
\end{tabular}




\begin{tabular}{|l|c|c|c|c|}
\hline $\begin{array}{l}\text { If ever consume then when leave tobacco } \\
\text { consumption }(\mathrm{n}=14)\end{array}$ & $9(81.8)$ & $2(18.2)$ & 11 & \\
$\begin{array}{l}<10 \text { years } \\
10-20 \text { years }\end{array}$ & $3(100.0)$ & $0(0.0)$ & 3 & 0.818 \\
\hline Total & $12(85.7)$ & $2(14.3)$ & 14 & 0.425 \\
\hline
\end{tabular}

Among 205 study population, almost 117 (57.1\%) was found to be consuming tobacco. The respondents consuming tobacco have forty times lesser chances of having aware of tobacco consumption as respondents not consuming tobacco $(\mathrm{OR}=0.025)$. The respondents consuming tobacco for more than 20 years and smoking more than 20 sticks per day were more aware of tobacco consumption but the difference was not significant (Table 2).

\section{DISCUSSION}

The Member countries of South-East Asia have been striving to increase the tax rates on tobacco products and strengthen the tax administration for tobacco control. Bangladesh is imposing duty and VAT on the unmanufactured tobacco products and smokeless products. India is going to introduce the Goods and Services Tax (GST) with cascading tax rates. Indonesia has simplified its tobacco tax regime while Thailand has kept increasing tax rates progressively in keeping with the rate of inflation. Although many countries have increased taxes in every fiscal year, over the last decade, cigarettes have become more affordable as inflation and the growth in per capita income have not been taken into account while raising the tax ${ }^{12}$.

Tobacco use and its pattern are closely linked to age, sex, education, income, etc. amongst many other factors. Findings from studies in the member countries of the region reveal that tobacco use is higher among the illiterate and poor population. The use of tobacco among the people in Bangladesh, India and Thailand was high ${ }^{12}$.

The awareness of tobacco consumption among the female was significantly higher (49\%) than male (33.0 \%) $(\mathrm{P}<0.05)$. Youth also have the perception that smoking makes them look more attractive. The Global Youth Tobacco Survey (GYTS) reports show that more than $20 \%$ of youth in Bangladesh, Myanmar, Nepal, Sri Lanka and Timor-Leste think that boys and girls who smoke look more attractive ${ }^{12}$. But in Nepal, educated women were four times less likely to smoke than those who were illiterate ${ }^{13}$. Smoking among adult women is much lower than men in some regions as it is socially not acceptable for women and tobacco use is restricted. Global Adult Tobacco Survey (GATS) reports reveal a huge variation in tobacco use between men and women. Tobacco use among women varies from $9.1 \%$ (Thailand) to $28 \%$ in Bangladesh ${ }^{12}$.

The awareness of tobacco consumption was recorded higher in those who were School Leaving Certificate $(\mathrm{SLC})$ and above $(44.6 \%)$ than illiterate $(25 \%)(\mathrm{P}<05)$. Literacy is found to greatly affect the rates of smoking among population. Findings of Global Adult Tobacco Survey (GATS) show that there is a significant difference in tobacco use among people by the level of education. For example, the tobacco use among people without formal education is three-fold higher than among those who have been schooled up to secondary and above in Bangladesh. The use of tobacco among illiterate people in India is twice as high as those who completed secondary education while Thailand also represents the same trend ${ }^{12}$.

The respondents below poverty line $(<1.25$ US\$) was less aware of tobacco consumption (37\%) than above poverty line ( $\geq 1.25$ US \$) (47.4\%) but the difference was not significant. People of lower economic classes in India tend to smoke bidis more and have a higher level of social acceptance than those in upper classes ${ }^{14}$. It is found that tobacco use is inversely related to income and wealth. People in the lower income brackets tend to use more tobacco than those in the higher income bracket. For instance, tobacco use is two times higher among the lowest income group than those in highest income group in Bangladesh ${ }^{15}$.

This study showed that the respondents only smoking was more aware (18.8\%) than both (smoking and chewing) (8.3\%) but none of the respondents was aware among only chewing but difference was not significant. In Nepal, tobacco chewing is more socially acceptable than smoking while smoking is considered 
MJSBH January-June 2015|Vol 14| Issue 1

as a symbol of independence among young people ${ }^{16}$. On the other hand, there is a gross misconception among people about tobacco use. About $40 \%$ of tobacco users in Thailand believe that a hand-rolled cigarette is less harmful than manufactured cigarettes and this belief is common particularly among population where its use is also high ${ }^{17}$.

The respondents smoking more than 20 sticks per day were more aware of tobacco consumption (20\%) than smoking less than 10 sticks per day (17.6\%) but the difference was not significant. But in another study, smoking more than 20 cigarettes per day was a significant predictor of cessation attempts and cessation success. The finding that smoking a higher number of cigarettes per day is associated with increased cessation success corroborates findings in the USA ${ }^{18}$. It is conceivable that heavier smokers may be more motivated to quit, as they are more likely to have experienced smoking related adverse health conditions, whereas light smokers might feel less motivation to quit because of a perceived lower personal risk.

The major limitation of our study was the low sample size. Another limitation is the cross-sectional nature of the original survey. This temporal ambiguity leads to the possibility of reverse causation of the observed effects. Smoking habits were assessed by self-report only, and are therefore subject to reporting and/or recall bias.

\section{CONCLUSIONS}

We conclude that the awareness towards the harmful consequences of tobacco consumption was found to be less. Male gender, lack of education, poor occupation like famer, housewife, students, abroad, labor, tailor, and carpenter was found to be less aware of tobacco consumption. The people those smoking more than 20 years and smoking more than 20 sticks per day were found to be more aware of tobacco consumption but the difference was not significant. Effective smoking cessation programmes may need to involve family members who may also be smokers. There is necessity for initiation of school based anti tobacco campaigns and reinforcement of such programs during graduation courses.

\section{REFERENCES}

1. Ezzati M, Lopez AD, Rodgers A, Vander HS, Murray CJ. Selected major risk factors and global and regional burden of disease. Lancet 2002; 360:1347-1360. http://dx.doi.org/10.1016/ S0140-6736(02)11403-6

2. World Health Organisation. WHO report on global tobacco epidemic 2008: the MPower package. Geneva Switzerland, 2010.

3. Peto R. Mortality from smoking in developed countries 1950-2000: indirect estimation from National Vital Statistics. Oxford: Oxford University Press; 2010.

4. World Health Organization. The impact of chronic diseases in Nepal. WHO 2002. Available on: http://www.who.int/chp/ chronic_disease_ report/en/. (Accessed on 20 July, 2015)

5. WHO South-East Asia Region. WHO World Health Survey. WHO Global InfoBase Version: 1.292beta 2001.

6. Pandey MR, Neupane $R P$, Gautam $A$. Epidemiological study of tobacco smoking behaviour among adults in a rural community of the hill region of Nepal with special reference to attitude and beliefs. Int J Epidemiol 1988; 17: 535-41. http://dx.doi.org/10.1093/ije/17.3.535

7. Pandey MR, Venkatramaiah $S R$, Neupane $R P$, Gautam A. Epidemiological study of tobacco smoking behaviour among young people in a rural community of the hill region of Nepal with special reference to attitude and beliefs. Community Med 1987; 9: 110-20.

8. Warren $C W$, Jones NR, Eriksen MP, Asma S. Global Tobacco Surveillance System (GTSS) collaborative group: Patterns of global tobacco use in young people and implications for future chronic disease burden in adults. Lancet 2006; 367:749-53. http://dx.doi.org/10.1016/S01406736(06)68192-0

9. Khan S, Mahmood SE, Sharma HK, Khan F. Tobacco use among medical students: are they the role models of the society. Journal of Clinical and Diagnostic Research 2013; 6: 605-607.

10. Karki YB. Review and situation analysis for comprehensive National Tobacco Control in 
Nepal 2002; available from: http://www.searo. who.int/Link Files/NMH_ CNTCnepal pdf. (Accessed on 20 July, 2015)

11. Zahiruddin QS, Gaidhane A, Bawankule S, Nazli $K$, Zodpey S. Prevalence and pattern of tobacco use among tribal adolescents: Are tobacco prevention messages reaching the tribal people in India? Ann Trop Med Public Health 2011; 4:7480. http://dx.doi.org/10.4103/1755-6783.85756

12. Kyaing NN, Islam MA, Sinha DN, Rinchen S. Social, economic and legal dimensions of tobacco and its control in South-East Asia region. Indian $J$ Public Health 2011; 55: 161-8. http://dx.doi. org/10.4103/0019-557X.89944

13. World Bank and World Health Organization (WHO). A Study on the Economics of Tobacco in Nepal. HNP Discussion Paper, Economics of Tobacco Control Paper No.13, 2003.

14. Gupta PC, Asma S, editors. Bidi Smoking and Public Health, New Delhi: Ministry of Health and Family Welfare, Government of India, 2008.
15. Efroymsona D, Ahmed S, Townsend J, Alam SMM, Dey AR, Saha R. Hungry for tobacco: An analysis of the economic impact of tobacco consumption on the poor in Bangladesh. Tobacco Control 2001; 10: 212-7. http://dx.doi. org/10.1136/tc.10.3.212

16. Government of Nepal, Ministry of Health and Population. Brief Profile Tobacco Control in Nepal. Katmandu, Nepal, 2010.

17. WHO. Regional office for South East Asia. Global Adult Tobacco Survey: Thailand Country Report. New Delhi, India, 2009. (Available from: http:// www.who. int/ tobacco/surveillance/thailand gats_report_2009.pdf). (Accessed on 20 July, 2015).

18. Levy DT, Romano E, Mumford E. The relationship of smoking cessation to sociodemographic characteristics, smoking intensity, and tobacco control policies. Nicotine Tob Res 2005; 7: 387- 396. http://dx.doi. org/10.1080/14622200500125443. 